\title{
TAF12 Gene Product
}

National Cancer Institute

\section{Source}

National Cancer Institute. TAF12 Gene Product. NCI Thesaurus. Code C139292.

A protein encoded by the TAF12 gene. 